\begin{tabular}{c} 
Volume and Issues Obtainable at Center for Sustainability Research and Consultancy \\
Journal of Accounting and Finance in Emerging Economies \\
ISSN: 2519-0318 ISSN (E) 2518-8488 \\
Volume 6: Issue 1 March 2020 \\
CSRᄃ \\
Journal homepage: www.publishing.globalcsrc.org/jafee \\
\hline
\end{tabular}

\title{
Role of Banks in Money Laundering through Fake Bank Accounts and Writing off Loan in Pakistan: An Analytical Study
}

\author{
${ }^{1}$ Rao Imran Habib, ${ }^{2}$ Attia Madni, ${ }^{3}$ Naureen Akhtar \\ ${ }^{1}$ Assistant Assistant Professor, Gillani Law College, Bahauddin Zakariya University Multan, Pakistan, \\ raoimran@bzu.edu.pk \\ ${ }^{2}$ Lecturer, Faculty of Law, International Islamic University Islamabad, Pakistan, atia.madni@iiu.edu.pk \\ ${ }^{3}$ Assistant Professor, Gillani Law College, Bahauddin Zakariya University Multan, Pakistan, \\ naureen.akhtar@bzu.edu.pk
}

\begin{tabular}{ll}
\hline \multicolumn{1}{c}{ ARTICLE DETAILS } & ABSTRACT \\
\hline $\begin{array}{l}\text { Hevistory } \\
\text { Available Online: } \text { March } 2020\end{array}$ & $\begin{array}{l}\text { Recent media reports of money laundering through fake bank accounts } \\
\text { implicate the involvement of banks in money laundering through } \\
\text { "managed bank accounts". Further the waivers of loan of apparently sound } \\
\text { institutions also give rise to specific questions and reservations on the role } \\
\text { of banks. This paper attempts to explore the answer to those fundamental } \\
\text { questions. The research follows qualitative content analysis methods to } \\
\text { Banks, Money Laundering, Loan, } \\
\text { Write off, Law }\end{array}$ \\
$\begin{array}{l}\text { critically analyze the role of banks in money laundering and loan waiver } \\
\text { policies. The research finds that despite of heavy banking regulations and } \\
\text { laws the banking accounts are being used for money laundering. Further, } \\
\text { the research concludes that the act of waiving off loans allegedly has } \\
\text { provided a channel to misuse the public earned money, resulting in gross } \\
\text { loss to the public exchequer. The research concludes that the role of bank } \\
\text { in maintaining the fake/idle accounts and the loan waiver policy and its } \\
\text { malafide usage in the banking sector resulted in financial frauds and } \\
\text { money laundering in Pakistan. }\end{array}$
\end{tabular}

(C) 2020 The authors, under a Creative Commons Attribution-Non

OPEN ACCESS

Commercial 4.0

Corresponding author's email address: raoimran@bzu.edu.pk

Recommended citation: Habib, R. I., Madni, A. \& Akhtar, N., (2020). Role of Banks in Money Laundering through Fake Bank Accounts and Writing off Loan in Pakistan: An Analytical Study. Journal of Accounting and Finance in Emerging Economies, 6 (1), 183-190

DOI: $10.26710 /$ jafee.v6i1.1077

\section{Introduction}

Banks act as an intermediary in financial transactions. They are licensed to accept money from the public and other financial institutions of the country. Banks provide financial services including safe deposits, currency exchange, premium bonds, credit accounts and mortgages on residential and commercial properties. The difference in the interest rate charged and paid is a profit of the Bank generated from different sources. Most of the countries in the world have institutionalized a system known as fractional reserve banking, which is crucial for the safety of general public money. Banks are the institutions which always deal with money. They generate money from money deposited by the public and charge money on 
a few types of accounts to keep their money safe. Banks charge money in lieu of those services which they provide to maintain the statements of the account holders (service charges) and pay money to account holders for using their money (profit). Hence banks are the institutions to channelize the public money and to protect it. (Michael McLeay, 2014).

The Central Bank of the states controls the national commercial banks and all other financial institutions within a state. These IFIs are subject to substantial laws and regulation which, ideally, should not leave any room for activities like money laundering. Money laundering, however, still exists as one of the most organized financial crimes which also involve the banks, in most of the cases. (Rafał Dreżewskia, 2015).The activity of money laundering involves the placement, layring and integration of the illegal funds, the black money. In placement, the black money is introduced in any financial institution or entity for example any bank or business venture for the purpose of cleaning. In second phase, layering, funds are directed through the complex financial system and move to the integration. Through this cycle of the black money gets cleaned and are then transmitted into the economy in form of any investments. (Unger, 2007). For instance, a public servant, when obtains bribe, which if included directly to his income, will defiantly raise question mark because it is much higher than his confirmed income. He has to bring this amount into the financial system by its placement into any bank account. It may be in the form of any bank deposits, purchase of any prize bonds, currency exchanges, investment into any company, or purchase of any tangible or intangible assets, or smuggling.( (J. C. Sharman, 2011).

Factors behind Money Laundering are Bribery, Tax Evasion, Weak Financial Regulations, Corruption and Failure of Banks in Detecting Laundered Money. (Nikolosk, 2012). Further absence of tracking system, which can automatically track the original Sources of Money and Lack of incentive, makes banks reluctant to work efficiently for the foolproof verification system. The Liberalization of Banking Sector without any check and balance is another main reason which paves the way for money launderers, Crime groups and drugs dealer to control the banking system. (Gilmour, 2016). The effects of these activities are far-reaching in an increasingly interconnected world. Money launderers and terrorist financiers take advantage of the complex international financial system, weak and ineffective legislation in different countries. This all helps those to get transfer the funds without being detected. (Hughes, 1991).

It sounds strange if one says that banks are channelizing and facilitating financial frauds and money laundering by opening and maintaining fake benami accounts but as a matter of facts the role of Bank, in this regard, cannot be negated. Currently, banks and other financial institutions, in Pakistan, are in the main firing line, by media, so far as money laundering is concerned. (Hannes Köster and Matthias Pelster, 2017). The current news regarding money laundering through the managed bank accounts and loan waiver by the banks to the companies, which are operating and solvent, also favours this hypothesis. Hence the research in hand focuses on exploring the role of banks in money laundering and other financial frauds, evaluate its impact upon public money and suggests numerous ways to overcome the issue of money laundering in Pakistan. (Sarigul, 2013).

\section{Fake / Benami Accounts and the role of Bank}

Efficiency and low cost of the transactions in banks and other financial institutions make them a preferable mean of committing money laundering. Moreover the complexity and overlapping involved in the banking also facilitates the launderer. Given the advantages of convenience, accessibility and safety in banking transactions, money launderers prefer to use banks to enter in international payment system. Upon availing access to international market, they can transfer black money via contemporary electronic means instead using old customary methods.

Most of the countries of the world initiated legislative measures against money laundering in the 1980s (Cassella, 2003). Pakistan, being a member of Asia Pacific Group (APG) promulgated corresponding national legislations on money laundering and terror financing. The State Bank of Pakistan (SBP) also 
issued regulation on Anti-Money Laundering and Combating the Financing of Terrorism (AML/CFT), in 2001. The State Bank of Pakistan also issued a circular on March 29, 2003. This circular amended the Prudential Regulation XI in apropos of Know Your Customer (KYC), Customer Due Diligence (CDD) policy. ( State Bank of Pakistan, 2003). These regulations provide the basic policies to minimize the activities of money laundering and terror financing in Pakistan. Among these regulations, Know Your Customer (KYC), Reporting of Transactions STRs/CTRs and Customer Due Diligence (CDD) are of utmost importance. Through these policies the central bank of Pakistan requires the Financial Institutions to be careful in their daily operation at banks. They are required to have complete knowledge of the customer's transactions and to report and take the proper action against fake and Benami account holders.

As legislative measures Anti-Money Laundering Ordinance, 2007 was promulgated to curb down the money laundering involving banks. The 2007 Ordinance focused mainly on the money laundering through banking transactions and made it mandatory for the banks to report the suspicious transactions. The 2007 Ordinance, however, had many flaws hence was amended several times finally it got replaced by Anti Money Laundering Act, 2010. (Azeem, 2012).Despite of these legislations Recent news about unearth money laundering through fake/ Benami bank accounts, in the names of 'Falooda' (a local sweet) vendors, factory worker and even dead man, by the investigating and regulatory authorities like FIA and FMU and issuance of notices to such persons by FBR and FIA has changed the perception of opening an account by oneself and making transactions from it. (Ahmad, 2017).

Notwithstanding the existence and importance of all these laws and banking regulation, there are certain factors that provide supportive environment for money laundering through banking medium. These factors include, but are not restricted to, the role played by financial institutions as advocate of the customer, the strange attitude of the banks towards account holder having strong balance sheet, the culture of secrecy adopted by every bank where they try to hide and protect every transaction of the customer, the secret reference, the lax and negligent controls and supervision and the rivalry with competing financial institutions. (Agarawal, 2005). Moreover the bank's customers may have different accounts in the same bank in which different transactions take place but banks ,in order to have more accounts and money ,ignore such activities. In fact, banks encourage customers to open multiple accounts without collecting the relevant information on these accounts. The supervision and control of these accounts is difficult and complex because of involvement of multiple sources, hence they prove to be perfect for the money laundering activities. Through such 'managed bank accounts' not only funds are routed to other accounts within the country or withdrawn without any ostensible trail available, but billions of rupees are transferred to numerous jurisdictions by skillfully structured methods. (Human Rights Case, 2018).

\section{Writing -Off Loans and the Role of Bank}

The write-off is an accounting term which means declaring the book value of an asset to be Zero. A loan write-off occurs when the lender (a bank or other financial institution) decides that a loan is not collectable and removes it from its balance sheet. When the lender realizes that it will not be able to recover its dues through the collection for a variety of reasons such as the borrower might not have the capacity to repay, the borrower is absconding. The borrower is bankrupt. It introduces policies like a write-off. Purpose of write off is to support accounting accuracy objective on the one hand and to reduction of tax liability by showing more expenses and less income. While a loan is active, it is an asset to have on the lender's balance sheet as it indicates that the lender owed money. However, when there is a minimal possibility of recovery of loan, the Bank has to write it off to reflect the diminishing of the value of the asset. (Ishaq, 2012).

Before writing off the loan bank should discuss or offer IVA (individual voluntary arrangement) to the customer. It is a successful scheme/ arrangement working in United Kingdom and many other countries in the world with different names. Usually, an insolvency practitioner deals with it and decide according 
to the client's circumstances whether the client meets the required criteria or not. Through this scheme, if a person is not able to return all or part of the money and financial institutions are not able to recover that loan, then he/she can enter into IVA. Financial experts help/guide/suggests the affordable monthly instalments for that person for a specific number of years (in the UK 5 years, 60 months). Through IVA, creditors always receive higher return then bankruptcy.(Angela Samantha Maitland Irwin, 2012).

The issue of written-off loans, in Pakistan, got highlighted recently when the Supreme Court of Pakistan (SC) issued notices to, appear before court, 222 individuals and companies who had got loan financing from different commercial banks from 1971 to 2009. Brief history of the matter is that a suo-moto action has been taken in the year 2008 by Supreme Court of Pakistan, after media reports broke the news that the State Bank of Pakistan (SBP) had allowed commercial banks to write off Non Performing Loan (NPLs). The loan waiver scheme was introduced by the former army chief and ex-president retired General Pervez Musharraf. In year 2011, a three-member commission headed by Mr. Justice Syed Jamshed Ali, a former judge of SC was constituted to investigate the legal standing of the loan waiver policy and the strategies of recovery of written-off loans from 1971 onward. The commission was directed to compile and submit a report. On completion of proceedings, the Commission submitted its final report before the three-member bench of SC headed by Chief Justice of Pakistan (CJP), Iftikhar Chaudhry, the Honorable SC then ordered that the report of the commission must be made public. (Iqbal, 2018). The report among all other points revealed that many of the beneficiaries of the loan waiver policy were solvent and the business entities were still operative.

In 2018, a two-member bench of SC headed by Chief Justice of Pakistan Mian Saqib Nisar again heard suo-moto case No. 26 of 2007 with HR cases and Constitution Petition No .64 0f 2009 etc. (Constitution Petition, 2009). Through this press release issued by SC of Pakistan dated on 9 August 2018, the borrowers were directed to either deposit the $75 \%$ of the differential between amount recovered and amount sanctioned before the registrar SC or their cases were to be referred to Banking Courts to reconsider the entire case. Although the cases are yet to be investigated and loss to Government Exchequer is yet to be determined, but the Commission in its report held that bankers are responsible for all the loss yet to quantify. The commissions suggested in its report that banks grant loan facility to customer, either short-term or long-term, on the provision of inadequate securities. The report declares it to be the violation of banking policies and suggested that proper action should be taken against those employees. It further suggested that the banks have been issuing loans on unjustifiable concessions, whether against political considerations or any other, which resulted in massive NPLs ( Consumer Protection Department, 2003).

Non-Performing Loans (NPL) is an intrinsic part of Bank's lending business across the globe. In the business of banking, taking risks cannot be avoided; rather, the whole idea rests upon taking calculated risks and managing them efficiently. However, in order to minimize NPLs, banks need to ensure robust due diligence. Banker's first and utmost objective is to see that if the account getting weak due to certain valid business reasons and may warrant an overdue / NPL status than a primary task is always to nurse it through difficult times by restructuring to help complete revival. (Wang, 2010). However, in times of systematic crises where the economy at large or a particular sector gets affected badly, NPLs are bound to happen, for which an altogether different approach is adopted to arrest further deterioration of assets. (Hopton, 2006). Ishrat Hussain, the Ex. Governor of the SBP while Analyzing the Written Off Policy of banks in year 1999-2003 tried to explain the confusion and misunderstanding of the people towards the write off loans policy of the SBP and its impact on the economy of Pakistan. (Hussian, 2002). He explains that when a loan becomes overdue by 90 days, then the unrealized mark-up will continue to be added in the total of Non-Performing Loan (NPLs). As a corollary stock of existing NPLs always grow even if all new loans are fully satisfied on due time Thus it should be noted that without any fault of the Bank, the aggregate value of NPLs escalates. 
The depositors (common public) who invest their money in banks to take interest to provide investments and capital to banks, which provides a buffer to banks, if broken leads the banks to fail.It is a common perception that when banks write off its loans, it is the owners of the money who should bear the loss. In the banking system, the owners of the money are the people/shareholders who invest their money directly in order to take profits out of it. (Ali Arfan, 2014). As the majority of the banks are publicly trader which means common people used to be shareholders to the capital available with the banks and any loss to the capital available with the Bank would be an ultimate loss to the public/shareholders. (Mirza, 2013).

The Courts of the Country are fully convinced that without the involvement of banks opening of fake/ benami accounts and money laundering through managed bank accounts was not possible. Judgments of numerous courts had depicted this view. In a Judgment in Muhammad Arif Teevno Vs. NAB through its Chairman, Division Bench of Sindh High Court has observed that as a bank manager, operation manager and compliance officer, petitioner has his specific roles and responsibilities to play and he intentionally failed to fulfil thus not entitled to claim relief of bail. Bail of the petitioner was rejected by the Honorable division bench of the Sindh High Court who was arrested on the allegations/grounds that being branch manager he was allegedly maintaining pension bank accounts through which pensions were paid to ghost pensioners against fake and fraudulent documents. (Muhammad Arif Teevno Vs. NAB , 2017). Similarly, in another case, Haq Nawaz Malik Vs. The State, Lahore, through the opening of fake bank accounts of widows huge amounts were misappropriated from the Benevolent Funds of Government, which showed involvement of the office of Benevolent Fund along with bank officials who helped to open a fake account of one Mst. Jannat Mai and its operation to withdraw amounts from the account of Government Exchequer allocated for pensioners. (Haq Nawaz Malik Vs. The State, 2002).

Banking Recoveries are made under Financial Institutions (Recovery of Finances) Ordinance 2001. Section 8 of the Ordinance, provide an ample regime for the recovery of written-off loans; however, the only impediment that may arise in future, after it is declared that a particular loan was written off based on considerations other than bona fide business considerations. The nexus that has been created with said provision with the Limitation Act, 1908 before initiating a proceeding under Section 9 of the Ordinance. The Limitation Act, 1908 provides three years time limitation for filing a suit for the recovery of writtenoff loans. ( Consumer Protection Department, 2003).Given the limitation prescribed in Section 8 of the Ordinance, even if certain cases are declared to be written off on the consideration other than bona fide business consideration or for political reasons the recovery, suits for the recovery of such written-off loans could not be filed because of being time-barred in terms of the provision on Section 8 of Ordinance. It is however, suggested if this limitation for claiming the amount of written-off loans is removed from Section 8 of FIO and the said section is amended appropriately, the banks then would be in a position to initiate recovery proceeding vis-à-vis the written-off loans under Section 8 of FIO. (Azeem, 2012).

\section{Conclusion}

Banks in Pakistan prioritize and set a target for their branch manager to bring more money into their branch to get their bonuses and promotions. Instead of focusing on the prevention of money laundering, their training focuses on generating more and more funds into their branches. While developed countries in the world concentrate on different types of training which help them minimize fraudulent transactions. There should be a special focus and training on account opening processes, especially for accounts opened by intermediaries on behalf of third parties (trusts and nominee accounts). Institutions should obtain satisfactory evidence of their identity to avoid or minimize the risk of fake accounts. Positive or negative role of banks in writing off debt cannot be determined at this stage when the matters are still sub-judice before Competent Courts of law. However, it can be analyzed from the above discussion that whenever there is a loss to public money or Government treasure, it is assumed that the policies were not made to favour the Government but individuals. As it is the institutions which are required to be strengthened, therefore, if any policy like write-off loans is introduced, loss to the institutions should be less than the 
benefit offered by such policy. However, it is recommended that in future institutions should be strengthened regarding their policy-making strategies.

\section{References}

Ahmad, W. (2017). An overview of Money Laundering in Pakistan and Worldwide: Causes, method and socioeconomic effects. Hein Journal, 300.

Ali Arfan, D. S. (2014). Doesa non-performing loan affect bank performance? Evidence from listed banks at Karachi stock exchange (KSE) of Pakistan. International Journal of Research in Social Sciences, 363-377.

Angela Samantha Maitland Irwin, K.-K. R. (2012). Modelling of money laundering and terrorism financing typologies. Journal of Money Laundering Control, 331.

Anti Money Laundering (AML) in Pakistan(2019). Bankers Academy.

Authority, H. K. (2018). Supervisory Approach on Money Laundering and Counter Financing Terrorism.

Azeem, Z. (2012). Pakistan's Legal Framework: Combating money-laundering and counter-terrorist financing. Business Recorder.

Cassella, S. D. (2003). Reverse Money Laundering. Journal of Money Laundering Control, 92.

Constitution Petition, 26 (The Supreme Court August 9, 2009).

Department, C. P. (2003). A Guide about Bank Accounts. Karachi: State Bank Of Pakistan.

Dr Ahmed Rukhsar, D. S. (2013). Money laundering in Pakistan. International Journals of Marketing and Technology, 247- 276.

Ellili, H. N. (2018). Anti-money laundering disclosures and banks' performance. Journal of Financial Crime, 98115.

Gilmour, N. (2016). Understanding the practices behind money laundering - A rational choice interpretation. International Journal of Law, Crime and Justice, 1-13.

Hannes Köster and Matthias Pelster. (2017). Financial penalties and bank performance. Journal of Banking \& Finance, 57-73.

Haq Nawaz Malik Vs. The State, PCr. LJ 739 (Lahore High Court, 2002).

Hopton, D. (2006). Money Laundering: A Concise Guide for All Business. Hampshire: Gower Publishing Company.

Hughes, S. J. (1991). Policing Money Laundering through Funds Transfers: A Critique of Regulation under the Bank Secrecy Act. International Law Journal, 283.

Human Rights Case, 39216-G (The Supreme Court, 2018).

Hussian, D. I. (2002). An Analysis of the Bank's Write-off (1999-2003). Dawn News, 22-26.

Iqbal, N. (2018). Loan write off the scheme. Islamabad: Dawn News.

Ishaq, M. R. (2012). Impact of Risk Management on Non-Performing Loans and Profitability of Banking Sector of Pakistan. International Journal of Business and Social Science, 307-315.

J. C. Sharman. (2011). The Money Laundry: Regulating Criminal Finance in the Global Economy. United State: Cornell University Press.

Laundering, A. G. (2009). Mutual Evaluation Report. Sydney, Australia: Asia/Pacific Group on Money Laundering.

Michael McLeay, A. R. (2014). Money Creation in the Modern Economy. Bank of England Quarterly Bulletin, 14.

Mirza, A. A. (2013). The Impact of Financial Liberalization on the Credit System of Pakistan: Historical Perspective. Research Journal of Recent Sciences, 74-80.

Muhammad Arif Teevno Vs. NAB, YLRN 177 (Sindh High Court, 2017).

Muhammad Subtain Raza, M. F. (2017). The Hawala System in Pakistan: A Catalyst for Money Laundering \& Terrorist Financing. Forensic Research \& Criminology International Journal, 2469-2794.

Nikolosk, S. (2012). Role of Banks as an entity in the system for preventing Money Laundering in Macedonia. Procedia- Social and Behavioural Sciences.

Pakistan, R. o. (2001). Anti-money Laundering and Combating the Financing of Terrorism (AML/CFT) Regulations for Banks \& DFIs. Karachi.: State Bank Of Pakistan. 
Pakistan, S. B. (2003). BPD Circular No.10, Prudential Regulation XI: Know Your Customer (KYC). Karachi: State Bank of Pakistan.

Pakistan, S. B. (2003). Prudential Regulation XI, Know Your Customer, circular no 10.Karachi: State Bank of Pakistan.

Rafał Dreżewskia, J. a. (2015). The application of social network analysis algorithms in a system supporting money laundering detection. Journal of Information Sciences, 18-32.

Sarigul, H. (2013). Money Laundering and Abuse of the Financial System. International Journal of Business and Management Studies, 285-301.

Suo moto, case No .26 (The Supreme Court 2 20, 2009).

Unger, B. (2007). The Scale and Impact of Money Laundering. Netherland: Edward Elgar publishing limited Willian Pratt House.

Wang, N. A. (2010). Financing Behavior of Textile Firms in Pakistan. International Journal of Innovation, Management and Technology, 130-135. 
